\title{
DNSによる開水路底面近傍速度場と 空間平均流速場の検証 \\ STUDY OF INSTANTANEOUS AND FILTERED FLOW FIELDS NEAR THE BED OF OPEN-CHANNEL FLOW BY DNS
}

\author{
中山昭彦1 \\ Akihiko NAKAKAYA \\ 1正会員 PhD 神戶大学大学院教授 自然科学研究科 (广 $657-8501$ 神戶市灘区六甲台町1-1)
}

\begin{abstract}
A direct numerical simulation (DNS) has been conducted to examine the near-wall structure of turbulence in rough-bed channel flow. It is intended to explore a better wall boundary condition in such simulation as Large-Eddy Simulation (LES) of open channel flows at high Reynolds numbers over rough bed. It is found that the instantaneous velocity profiles cannot be described by the instantaneous logarithmic-law similarity. The filtered velocity field is found to be closely related to the magnitude of the filtered temporal normal velocity near the bed. It agrees with the previous study based on experimental data and indicates that the near-wall velocity field over rough surface is related more to the sweep-ejection type modes of motion than the local and temporal values of the wall shear stress. A possible wall model using an assumed shear correlation is suggested.
\end{abstract}

Key Words : DNS, LES, wall turbulencel, open-channel flow, turbulence structure

\section{1.はじめに}

$$
\text { ラージ・エディー・シミュレーション (LES) 法は , }
$$

普遍性の高い相似則が成り立つとされる小スケール乱れ をモデル化し，解像可能な大スケール運動を計算するも ので师用性か澌待されいろいろな乱流の計算に応用され 始めている.サブグリッドスケール (SGS) 乱流応力に は種々のモデルか提案され固定境界のない流れや低レイ ノルス数壁乱流などで成果がでており，従来のレイノル ズ平均式を基にした計算法にとって代わろうとしている

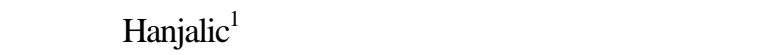
するには, 解像の出来ない壁面近傍小スケール流れを巧 くモデル化する必要があるが, いまだ適確な方法は確立 されていない．とくに実河川など底面力複雑な粗面であ る場合炎の扱いは困難で, LES法の実問題への適用の大 きな障害になっている.これまて粘着壁近傍の境界条件 として部分スリップやべき乗か坂定されたりしている2 が, 最も一般的なものは瞬時の壁面摩擦速度を基にした 対数則に従うとするものである゙ . しかしこれらの法則 は一般的に成り立たず，他に方法かないためやむを得ず
用いられているのか現状である (例えばSalvetti et al. $\left.{ }^{4}{ }^{4}\right)$ ． 本著者らは (Nakayama et al. ${ }^{5)}$ ) は熱線列を用いた風 洞実験により瞬時速度分布を計測し, 高レイノルス数及 び粗面境界層壁面近傍の瞬時速度分布とフィルター平均 された速度分布の相似性を調へだ . その結果, 壁法則領 域では, スイープ型とイジェクション型の速度分布が， 瞬時壁面摩擦速度の变動及び壁面法線方向速度の变動と 連動していることが見出された . しかし瞬時摩察速度を 基にした瞬時ベースの壁面法則にあたるものは見出され ていない . 特に通常のLESで用いられる境界条件である 対数則や先れを改良したもの (Schumann ${ }^{6)}$, Piomelli et al. $\left.{ }^{7}\right)$ (は検証されず，1次元的空間フィルタリングでは 粘性スケールの1000部以上のスケールでフィルター平均 された速度場て対数則に近づくことが示されている.粗 面の場合, 瞬時摩擦速度は重要なパラメータではないが, 圧力による形状抵抗も考慮する必要があり求めるのは困 難で, 弚れに替わる瞬時速度スケールとしてr oughness I ayer のすぐ外側での速度が適当である .

本稿では, 直接数值シミュレーション (DNS) を行う 事により，上記の実験では得られない底面近傍の瞬時速 度分布を求め, 光れに空間フィルター施し, LESシミュ 
表- 1 計算条件

\begin{tabular}{|c|c|c|c|}
\hline & $\begin{array}{c}R e \\
U_{m} H / v\end{array}$ & $\begin{array}{c}\text { 粗度高さ } \\
\delta / H\end{array}$ & $\begin{array}{c}\text { 平均摩擦速度 } \\
U^{*} / U_{m}\end{array}$ \\
\hline 2 次元粗度 & 6760 & 0.02 & $0.075_{s}$ \\
\hline 3 次元粗度 & 6760 & 0.02 & 0.073 \\
\hline
\end{tabular}

(a) 2 次元粗度

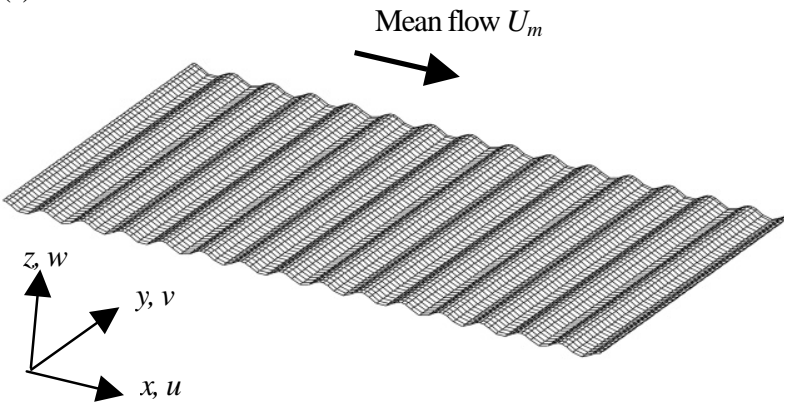

(b) 3 次元粗度

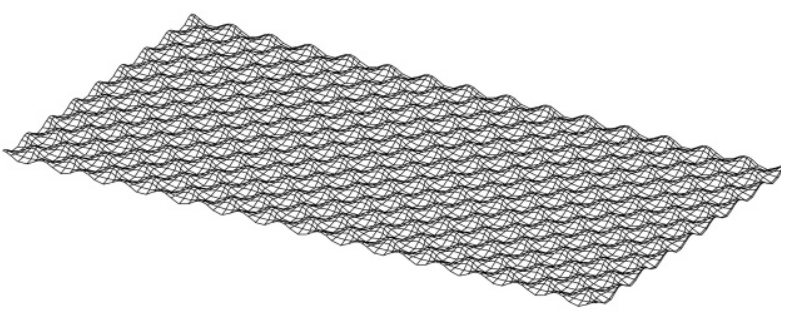

図 1 モデル粗面（曲線は計算に用いられた格子線で底面 上のものを 2 本おきに描いたもの)

レーションで必要な境界近傍の速度場の相似性を検証す る.レイノルス数は平均流速と水深を基にしたもので 6760と大きくはないが, 対数則領域の幅は十分あり壁面 境界近傍の特性を調べるには十分である . 用いるDNS言十 算法(は以前著者 ${ }^{8)-10)}$ か行った開水路乱流の直接シミュ レーション計算法を光のまま用いた . 近年 , 粗面乱流の 直接数值シミュレーションはいくつかの研究グループで 行われているが(11),12)いずれも角柱や直方体ブロックなど 空間平均との関連を調べるのか灘しい形状のもので, 実 際空間平均量を定義し考察した例はない，本研究では

フィルタリングを比較的単純に行える正弦波状粗面を扱 う.これには境界形状に沿う一般曲線座標を用いること も可能である .

\section{DNG言十算}

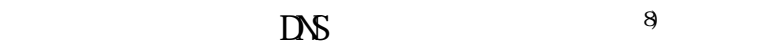
Nakayama \& Sakio9 のDN計算で用いられたものと同一 (a) 2 次元粗面

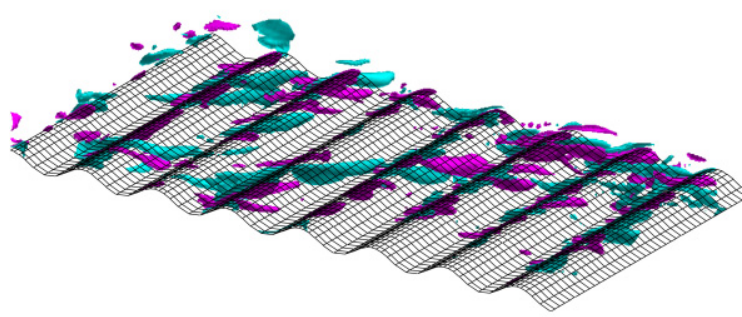

(b) 3 次元粗面

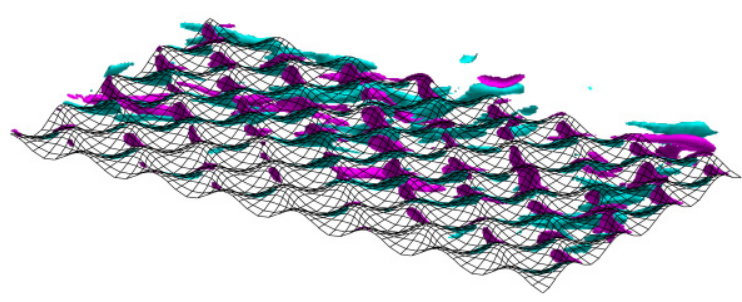

図- 2 全計算領域の1/4の領域の底面近傍での主流方向渦 度の等値面 (赤は正, 青は負の值の等値面)

のもので, 境界適合一般座標上コロケート格子を用いた Fr act i onal - step法である .この方法で得られた結果は 平坦開水路流及び，波状境界面上流れについて既往の実 験や計算結果と比較し検証されている .

DNS計算は図-1に示す 2 種の粗面底面上の開水路等流 について行われた . 滑面流れについては以前に計算を 行っている8 . 計算領域は水深 $H$ に対し流れ方向 $L=3 H$, 横方向 $W=1.6 H$ で主流方向及び横断方向には周期境界を 与えている. 本研究では底面近傍の乱机に注目している ので , 水面は固定スリップ面と仮定している . 粗面は 2 次元正弦波及び3次元正弦波からなるもので，正弦波波 長は $\lambda=0.2 H$, 振幅は $\delta=0.02 H$ である. この振幅/波長比の 場合個々の波の起伏部の下流で流れ力渌漓倠 , 再付着する 砂粒粗度に相当するいわゆるk型粗面である. 計算の諸 量は表-1に示してある . 粗度の高さ $2 \delta$ と平均摩擦速度 U*を基にした粗度レイノルズは20で粘性が無視できな い遷移粗度である.計算格子は流れ方向 , 水深方向 , 横 方向に301× 145× 160で, 同樣のレイノルズ数のチャン ネル流DNSに比べやや少ない格子数での計算であるが， 水面での格子密度をやや粗くとることにより効率を良く している。

本シミュレーションで得られた瞬時流れ場の概要は 図-2の主流方向渦度の等値面 (正負の二つの值) により 示されている . これは計算領域全体の1/4の領域の底面 近傍を拡大したものである . 粗面乱流の瞬時構造は Tsujimoto et al. ${ }^{12)}$ のシミュレーションでも滑面壁乱流と大 きく変わらないことか報告されている.3次元粗面流れ は壁面極近傍で渦構造がや乱されているのが見られる が, 双方とも滑面流れの構造に比へ，流れ方向長さはや や短い特徵になっている。 


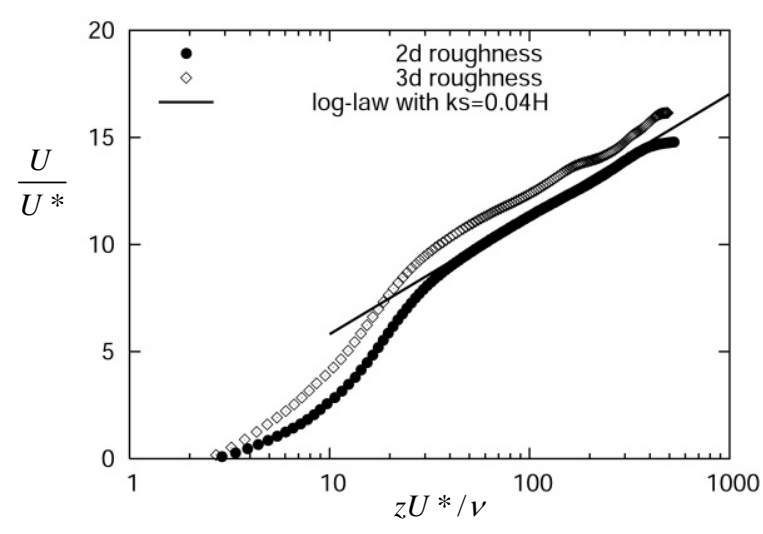

図- 3 平均速度分布

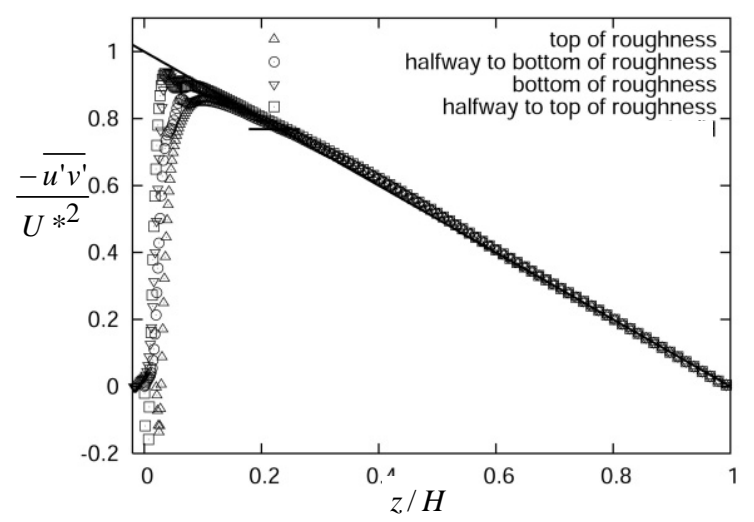

図-4レイノルズせん断応力

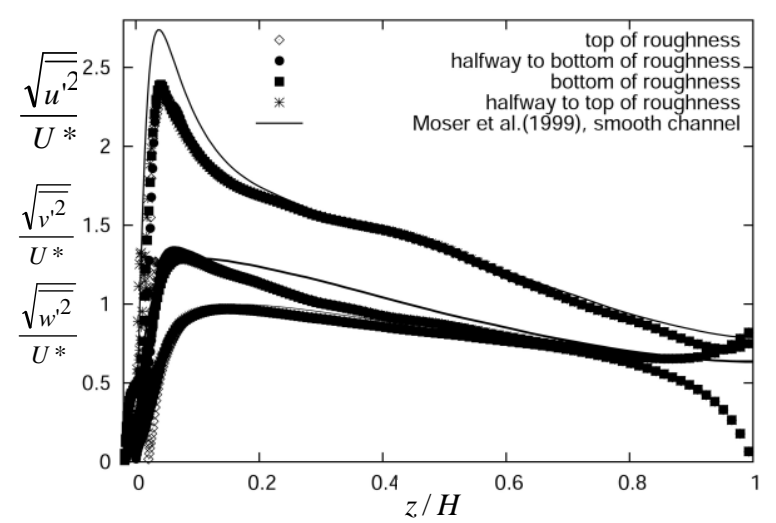

図- 5 乱流強度分布

時間及び流れ方向及び横方向に空間平均を施した流速 分布は図-3に粗面対数則

$$
U / U^{*}=\frac{1}{\kappa} \log \frac{z}{k_{s}}+8.5
$$

とともにプロットされている .ここでU は平均速度， $U^{*}$ は平均摩擦速度, $z$ は平均壁面位置からの鉛直距離, $k_{s}$ は等価粗度で火はカルマン定数である . 図示されてい る対数則の $k_{s}$ は, 比較として正弦波粗度の総高さである 振幅の 2 倍の $0.04 H$ にとっている. 平均摩擦速度は平均 圧力勾配より求めたものである．2 次元粗面上の流れは (a) 2 次元粗面

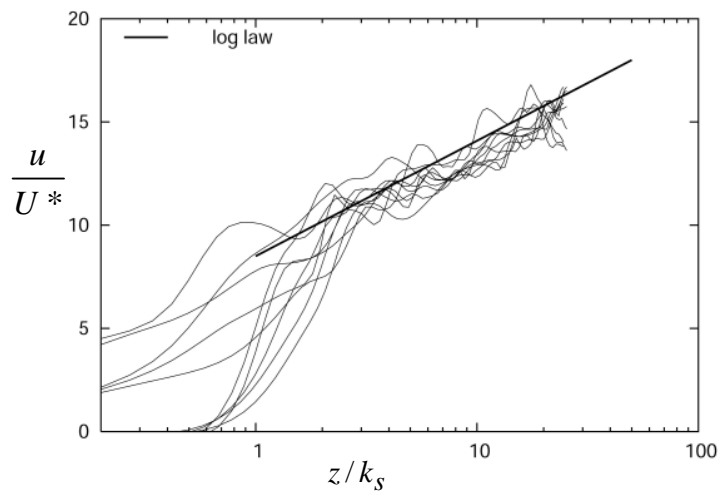

(b) 3 次元粗面

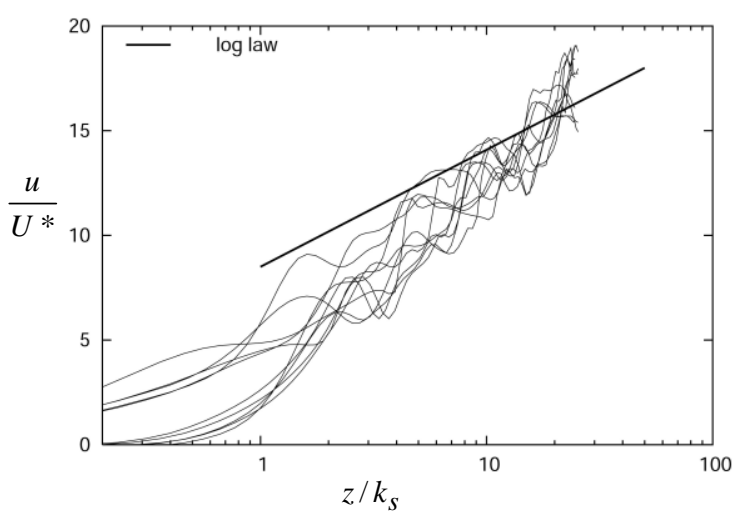

図 6 瞬時速度分布の対数則プロット

表- 2 空間平均フィルターサイズ

\begin{tabular}{|c|c|}
\hline & $\Delta x \times \Delta y \times \Delta z$ \\
\hline フィルター1 & $0.12 H \times 0.10 H \times 0.06 H$ \\
\hline フィルター2 & $0.24 H \times 0.20 H \times 0.12 H$ \\
\hline
\end{tabular}

水面近傍を除けばこの対数則と良く一致している.また 3次元粗面流ではこの線よりやや上方にずれている．3 次元粗面では流れ方向に投影した突起断面積がさくま た山の部分の密度が小さいためか, 等価粗度は実際の粗 度高さよりやや小さいことを示唆している . 実際の砂粒 粗度の場合粒度分布があるので, 乱れ生成に大きく寄与 する粗度要素は平均高さより大きい，したがって本DNS の大きさの一樣な3次元粗度モデルの場合, 光の高さは 粒度分布のある場合と比心小さくなるのは予想される . 壁面の実質原点の正確な位置の取り方はさらに難しいの で今回は平均境界の位置としている .

レイノルズせん断応力と乱れ強度の計算結果は 2 次元 粗度のもののみであるが , 图-4及び図-5に , レイノルズ 数がほぼ同等のチャンネル流DNS (Moser et al. ${ }^{13)}$ ) と比 較してある. 本計算結果からは粗度の頂上 , 底及び中間 の4点でのプロファイルをプロットしてある . これら 4 点での差は粗度の高さ程度以内のところでのみ差がある 
(a) 2 次元粗面 , フィルター1

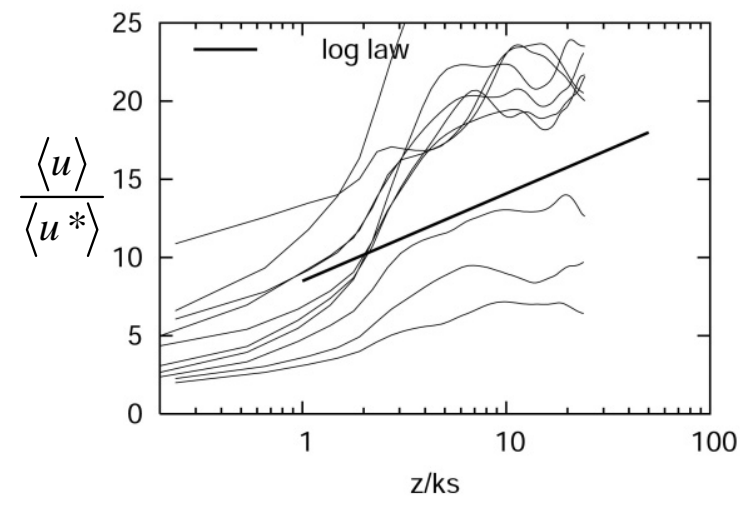

(b) 2 次元粗面, フィルター2

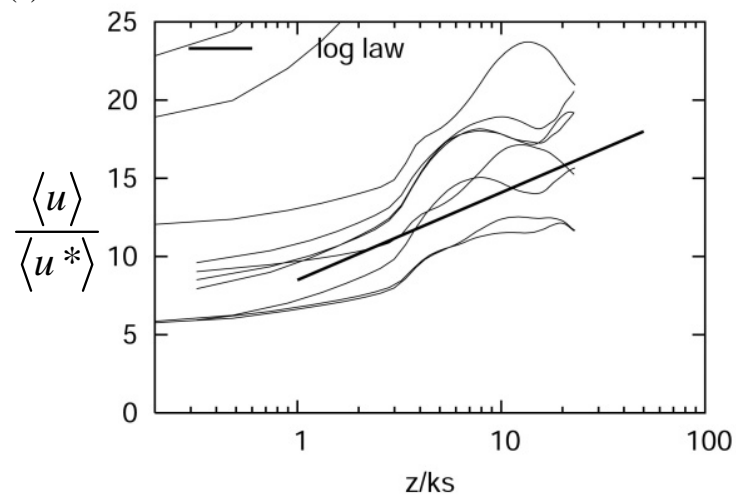

(c) 3 次元粗面 , フィルター1

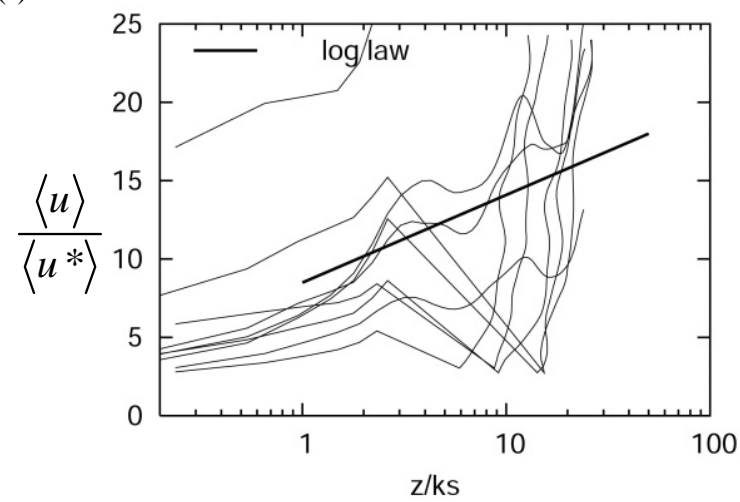

(d) 3 次元粗面, フィルター 2

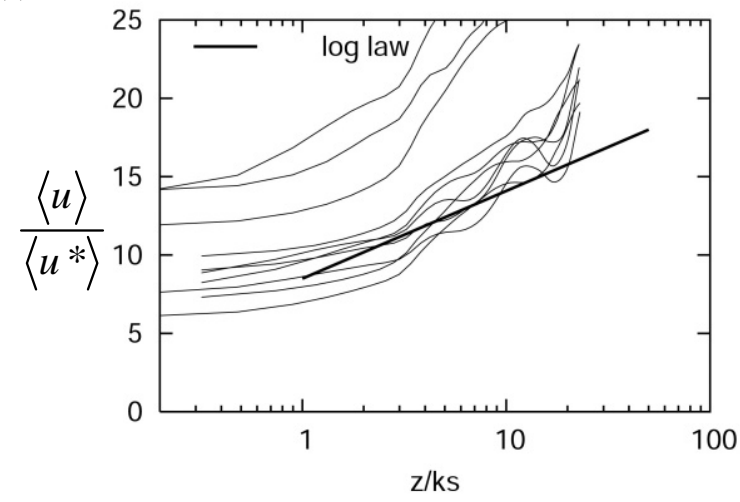

図- 7 フィルター平均速度分布

が弚れ以外の領域では差は殆どない，水面近傍では水面 減衰効果が見られ，底面近傍では流れ方向乱れは小さく， 横方向乱れは大きくなり，粗面乱流の等方性傾向力碓認
される . すなわち乱流強度の結果も良好であると言える .

\section{3 . 瞬時流速プロファイル}

図-6(a),(b)に十分離れた10点での瞬時速度分布を示す． 横軸は底面からの距離 $z$ を等価粗度 $k_{s}$ て無次元化し， 縦軸は瞬時速度 $u$ を平均摩擦速度 $U^{*}$ て無次元化した ものである. $k_{s}$ には, 2 次元粗度, 3 次元粗度に差は あるものの，実際の高さ2dに近いのて暫定的に2 2 とした . 10個の速度分布だけでは十分ではないが，およ光の分布 の変動幅は分かる . 粗面乱流であるので, $z k_{s}<1$ の壁面 極近傍では大きい変動になっているが, $z / k s>5$ の対数則 領域でも 2 次元粗面，3次元粗面とも個々の速度分布は 対数分布からかなりずれており、瞬時速度場には相似性 がしく，乱れ成分が支配的であることが分かる．

\section{4 . フィルター平均速度プロファイル}

次に空間フィルター平均した速度場について調べる． すなわち上記の直接シミュレーション結果に次のような 陽的フィルター積分を行う.

$$
\langle u(x, y, z)\rangle=\iiint u(\xi, \eta, \zeta) G(\xi-x, \eta-y, \zeta-z) d \xi d \eta d \zeta
$$

ここで〈〉はフィルター平均を意味し， $G$ はフィルター 関数であるが, 本計算では $x, y, z$ 方向に幅 $\Delta x, \Delta y, \Delta z$ の トップハットフィルターを用いる .フィルター幅は 2 通 り取られ表-2のように光れ光れフィルター1，フィル ター2 と呼ぶ . フィルター1は粗度 2 個分の大きさで粗 面の凹凸を平滑化する最小の幅のもので, フィルター2 は光の約2倍である .

（1）フィルター平均摩察速度による無次元化

図-7に, 図一6の流れに上記の2つのフィルターをかけ たものを示す . 横軸は図-6と同じであるが . 縦軸には フィルター平均された摩擦速度 $\langle u *\rangle$ て無次元化した速 度をとっている. $\langle u *|$ は境界面でのみ值があるので， 面フィルタリングで与えられる.ここでは $\Delta x \times \Delta y$ の水平 面に相当する境界面でフィルター平均された抵抗から算 出された摩擦速度である . 瞬時の局所摩擦の值は大きく 変化し, 符号も変わるのでプロットするまでもなく, 大 きな変動になる . 本プロットはLESの境界条件として使 われる場合 (例えばDeardorff ${ }^{3)}$ ) を検証したものである . フィルター幅の大きい方では全体的に変動が㭂く，対 数則に近づているが, 瞬時ベースの相似則があるとは 言えない．これは実験結果も同樣である . しかしフィル ター平均した分布は壁面近傍で骨らかな分布になってき ており何らかの相似性か期待される . 栈粗度についての 
(a) 2 次元粗面 , フィルター1

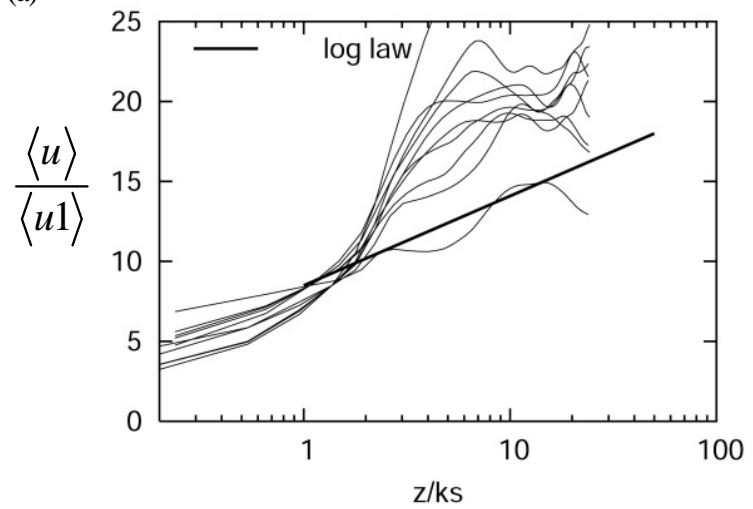

(b) 2 次元粗面 , フィルター 2

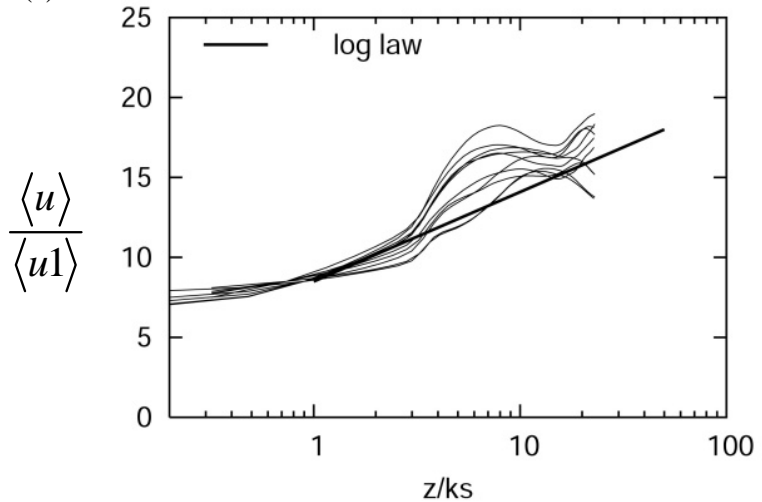

(c) 3 次元粗面, フィルター 1

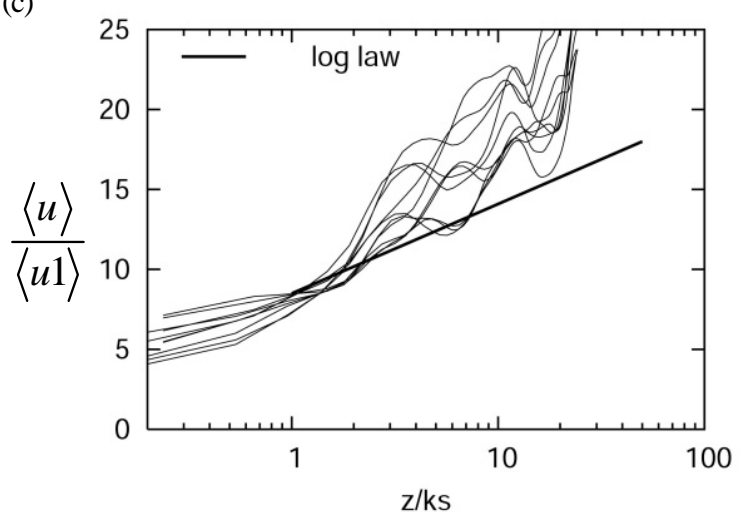

(d) 3 次元粗面 , フィルター2

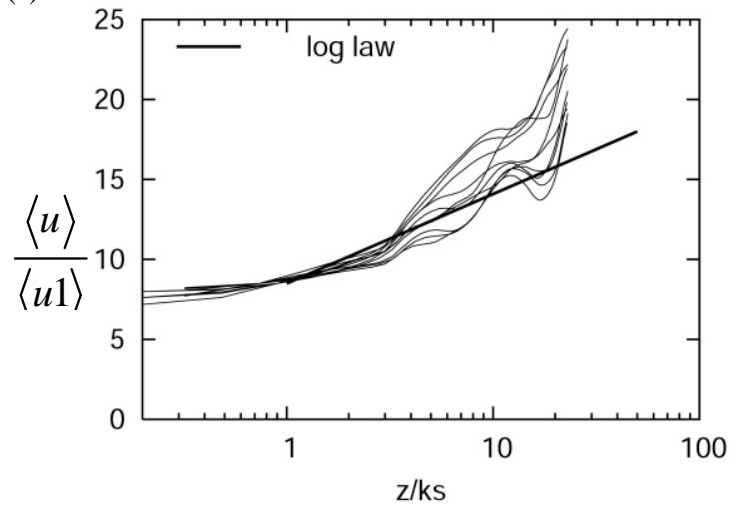

図- 8 r oughness I ayer 速度スケールにより無次元化され たフィルター平均速度分布

実験からは粗度高さの1.5倍程度の位置の瞬時速度力瞬 時速度分布のスケールになっていることが見出されてい る.
（2）Roughness I ayer 代表速度による無次元化

次にRoughness I ayerの位置とされる $z=k s$ でのフィ ルター平均速度 $\langle u 1\rangle$ て無次元化した速度分布を図- 8に示 す. $\langle u 1\rangle て ゙$ 無次元化されているので，z/ks=1では標準対 数則に乗る . 注目すべきはある程度のフィルタ一幅で空 間平均すると， $z / k s=1$ からやや離れたところでも対数則 に近づいているということである .これは , Roughness I ayerではフィルター平均量はある種の壁面則を持って いることを示唆する . ただこれだけでは壁面摩擦応力と の関連か得られない .

上記の考察より，壁面での実際の壁面抵抗と $\langle u 1\rangle$ との 関係を調べる . 本DNS計算結果からは底面上の瞬時圧力 及び粘性応力を積分することにより壁面抵抗を計算する ことが出来る . 図-9はこうして求めた抵抗值より算出し た壁面摩擦速度 $\langle u *\rangle$ と $\langle u 1\rangle$, さらに同じ点での鉛直速 度 $\langle v 1\rangle$ の水路中心線上での分布をプロットしたものであ る. $\left\langle u^{*}\right\rangle$ はフィルター平均であるが, 2 次元粗度， 3 次元粗度とも境界の凸凹により大きく変化している．し かしフィルター平均量の $\langle u 1\rangle,\langle v 1\rangle$ は変動が滑らかで, しかもの相関は強いことが見て取れる．これは，これら の速度成分にせん断相関力強いということである . 乱流 構造の観点からいうとイジェクションとスイープの運動 にあたる14) . すなわちこういつた構造は大規模運動に関 係があり，LESで扱うフィルター平均された速度成分の 運動にもこの構造力残っているということで, LESモデ ル構築に有用な特性である . 例えば極端ではあるが， $\langle u 1\rangle$ と $\langle v 1\rangle$ の変動成分 $\langle u 1\rangle^{\prime}\langle v 1\rangle^{\prime}$ が

$$
-\langle u 1\rangle^{\prime}\langle v 1\rangle^{\prime}=\langle u *\rangle^{2}
$$

と仮定するとこの乱流応力は壁面抵抗と一致し，しかも この関係を壁面則のとして使える可能性がある .

\section{5.まとめ}

開水路等流の DNS 計算の瞬時速度場特性を調べること により, 実用的乱流シミュレーションに必要となる粗面 壁近傍のモデリングの検証を行った . DNS 計算はレイノ ルズ数の低い流れではあるが, 十分な対数則領域を持つ もので壁面モデルの検証には十分である．2次元正弦波 および3次元正弦波状の粗面を考えたか境界極近傍での 構造に差はあるものの壁面からやや离倠れた roughnss I ayer の外側領域では両者に差は見られない, どちらも 瞬時速度場は大きく乱れ対数則などの相似則には沿わな い.フフィルター平均量は壁面乱流の大規模構造を捉えス イープやイジェクションなどの運動が見られ特にせん断 相関は非常に強いので, 例えば垂直方向変動速度成分と 主流方向変動速度の変動值の積力瞬時抵抗で与えられる 
(a) 2 次元粗面 , フィルター1

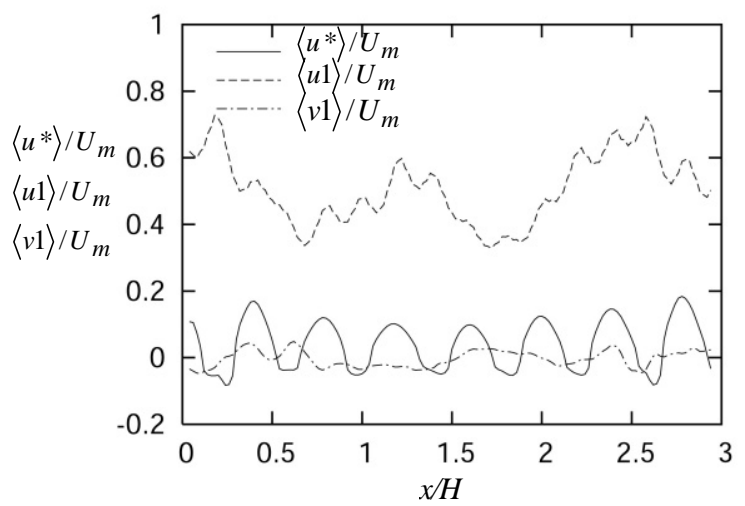

(b) 2 次元粗面 , フィルター2

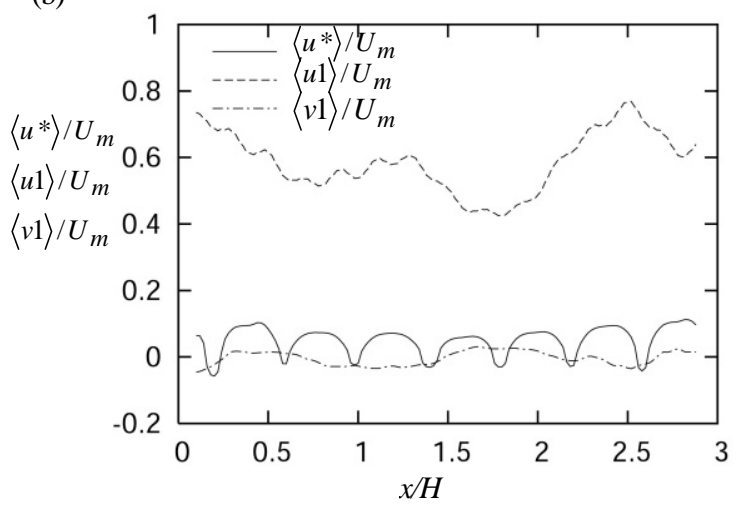

(c) 3 次元粗面 , フィルター 1

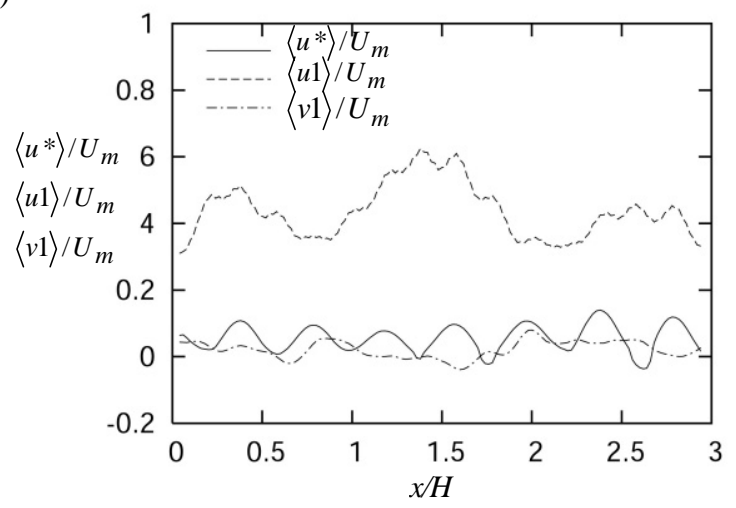

(d) 3次元粗面, フィルター2

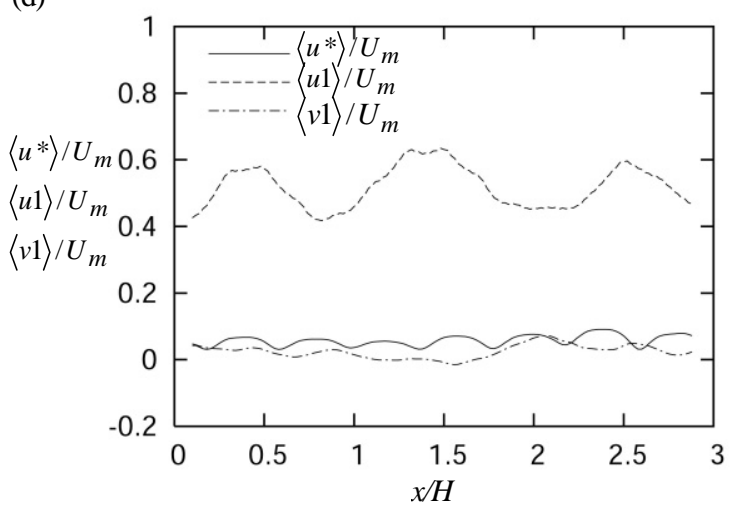

図-9 フィルター平均された摩察速度と roughness I ayer 速度スケールの分布
というような壁面モデルか洧用であることを示唆してい

る.

\section{参考文献}

1) Hanjalic, K.: Will RANS survive LES? A view of perspective, $J$. Fluids Engnrng, Vol. 127, pp.831-839, 2005.

2) Werner, H. and Wengle, H. : Large-eddy simulation of turbulent flow over and around a cube in a plane channel, Proc. Eighth Symp. On Turbulent Shear Flows, pp.19.4.1-19.4.5, 1991.

3) Deardorff, J.W.:A numerical study of three-dimensional turbulent flow at large Reynolds numbers, J. Fluid Mech.Vol.41, pt2, pp.453-480, 1970.

4) Salvetti, M.V. Damiani, R. and Beux, F. : Three-dimensional coarse large-eddy simulations of the flow above two-dimensional sinusoidal waves. Int. J. Nume.l Meth Fluid, 35, pp. 617-642, 2001.

5) Nakayama, A, Noda, H. and Maeda, K. : Similarity of instantaneous and filtered velocity fields in the near wall region of zero-pressure gradient boundary layer, Fluid Dynamics Research, Vol. 35, No. 4, pp. 299-321, 2004.

6) Schumann, U.: Subgrid scale model for finite difference simulation of turbulent flows in plane channel and annuli, $J$. Comp. Phys. Zvol.18, pp.376-404, 1975.

7) Piomelli, U., Ferziger, J. and Moin, P. : New approximate boundary conditions for large eddy simulation of wall-bounded flows, Phys. Fluids, A1, pp.1061-1068, 1989.

8) 横嶋 哲, 中山 昭彦: 水面変動を伴う開水路乱流の直接 数值シミュレーション, 土木学会論文集, Nb. 712/II-60, pp. 57- 72, 2002.

9) 中山 昭彦, 崎尾 幸司: 波状粗面上乱流の直接数値シ ミュレーション, 土木学会応用力学論文集, Vol.6, pp. 839 846, 2003.

10) 中山 昭彦, 崎尾 幸司: 複杂隹境界上乱流のフィルタ平均 とLES, 水工学論文集, 第48巻, pp. 613 618, 2004.

11) Leonardi, S., Orlandi, P., Smalley, R.J., Djenidi, L. and Antonia, R.A. : Direct numerical simulation of turbulent channel flow with transverse square bars on one wall, J. Fluid Mech., Vol. 491, pp. 229-238, 2003.

12) Tsujimoto, K., Miyake, Y. and Nagai, N.: Direct numerical simulation of turbulent mixing in a rough-wall flow, DNS/LES Progress and Challenges, pp.541-548, 2001.

13) Moser, R.D., Kim, J. and Mansour, N.N.: Direct simulation of turbulent channel flow up to Ret=500, Phys. Fluids, Vol.11, pp.943-945, 1999.

14) Jimenez, J. Turbulent Flowa over Rough Walls, Annu. Rev. Fluid Mech., Vol.36, pp.173-196, 2004.

(2005. 9. 30受付) 